\title{
ANTITHYROID ACTIVITY ELICITED BY THE INGESTION OF PURE PROGOITRIN, A NATURALLY OCCURRING THIOGLYCOSIDE OF THE TURNIP FAMILY *
}

\author{
By MONTE A. GREER ANd J. M. DEENEY \\ (From the Division of Endocrinology, Department of Medicine, University of Oregon Medical \\ School, Portland, Ore.)
}

(Submitted for publication March 17, 1959; accepted April 2, 1959)

Foodstuffs of various sorts have been implicated as a cause of goiter for many years. Only by the discovery of Chesney, Clawson and Webster in 1928 that cabbage feeding would result in thyroid enlargement in laboratory animals (1) were these vague hypotheses started on a firm experimental footing, however (for detailed review see Reference 2).

Although various articles of diet have been reported to produce goiter in diverse animal species since that time, studies employing the acute inhibition of thyroidal radioiodine accumulation indicated that only a relatively small number of foods possessed antithyroid activity in man (3). Of these, rutabaga was consistently the most potent. Eventually it was possible to isolate and identify the active agent in this species, $l$-5-vinyl, 2 -thiooxazolidone (4), more recently termed "goitrin" (5). Goitrin has been identified in the seeds of most Brassicae but until recently in the edible parts of only rutabaga and turnip. It has now been reported that goitrin has been detected in the edible portions of cabbage, kale and rape $(6,7)$. As yet no other naturally occurring antithyroid compound with pathogenetic significance for man is known to exist.

Very early in the studies isolating goitrin it became apparent that this substance did not exist in the free state but was bound to a precursor from which it could be liberated by a crude enzyme preparation, myrosin, prepared from crucifers. Myrosin supposedly is or contains a specific thioglycosidase which hydrolyzes mustard oil thioglycosides (8).

* Supported in part by United States Public Health Service Grants A-2503 and A-1447. Presented in part at the 1958 Meeting of the Western Society for Clinical Research. Greer, M. A., and Deeney, J. M. Physiologic studies with pure crystalline progoitrin. Clin. Res. 1958, 6, 90.
The original studies of the antithyroid activity of foods in man had indicated that cooking would usually destroy the potency of rutabaga and turnip. Goitrin also could not be isolated from cooked material but would appear when such preparations were treated with myrosin (9). This led to the assumption that the precursor, called "progoitrin," could be hydrolyzed only by the myrosin contained in the crucifer and that cooking, by denaturing the enzyme, would prevent the active goitrin from being formed. Thus only the ingestion of raw rutabagas or turnips was considered as potentially leading to the development of goiter (9).

Recently the isolation and identification of progoitrin as a thioglycoside has been accomplished (5). A relatively simple method of preparing sizable amounts of pure, crystalline progoitrin by elution from an anion exchange resin has been devised. This has permitted an experimental examination of our original hypothesis. To our surprise, we have found that progoitrin can be converted quantitatively to goitrin in the body by both man and rats without the addition of exogenous myrosin.

\section{MATERIALS AND METHODS}

Crystalline progoitrin was prepared from a 75 per cent acetone extract of ground rutabaga or kale seed by elution with sodium chloride from an anion exchange column. The method is to be presented in full in a separate paper (10). Purified goitrin and myrosin (8) were also prepared from rutabaga seed.

Goitrin was assayed in biological fluids by extracting with peroxide-free ether, evaporating the ether extract, dissolving the residue in distilled water and reading the absorption at 230, 240 and $250 \mathrm{~m} \mu$ in a Beckman spectrophotometer. Goitrin has a maximum specific absorption at $240 \mathrm{~m} \mu$ (4) as compared to 227 for progoitrin (5). In addition to the different absorption maxima they are easily distinguished by the fact that goitrin is equally soluble in ether and water while progoitrin is insoluble in ether. 
Acute tests of antithyroid activity in man were made by two methods. In one a modification of the technique of Stanley and Astwood (11), utilizing a change in the slope of the "accumulation gradient," was employed. Ten $\mu \mathrm{c}$. of $\mathrm{I}^{131}$ was administered to subjects and counts made over the thyroid region with a collimated scintillation counter every 10 to 20 minutes for the first four hours and every 45 to 60 minutes for the next four hours. A final reading was taken at 24 hours. Counts taken over the lower thigh were assumed to represent background and were subtracted from the neck radioactivity at each interval. Each corrected neck count was plotted as per cent of the administered dose on the ordinate against the square root of the time in minutes from administration of the radioiodine on the abscissa. From such a plot a straight line is formed which persists for the first eight to 12 hours. After the slope of the accumulation gradient had been determined, progoitrin with or without added myrosin was administered orally. Antithyroid activity could be detected by a deviation of the subsequent neck counts below the extrapolated slope. In addition, the expected 24 hour uptake, as calculated by a previously determined formula using the slope of the accumulation gradient (12) was compared with that actually obtained.

The second method employed an initial 24 hour thyroidal radioiodine uptake. Progoitrin was then administered orally and followed by a second 24 hour uptake study one to three hours later. Urine was collected quantitatively and assayed for goitrin by the method described above. Blood was also drawn for goitrin assay at various intervals before and after administration of progoitrin.

In two subjects, purified but noncrystalline goitrin was given to compare its metabolism and activity with progoitrin.

In three patients, progoitrin was administered through a $30 \mathrm{~cm}$. rectal tube. The patients were placed in a prone position with the trunk flexed downward almost $90^{\circ}$ over the edge of the table. Progoitrin was dissolved in $20 \mathrm{ml}$. of saline and allowed to flow into the colon by gravity. Two successive rinsings, each with $20 \mathrm{ml}$. saline, were then made through the tube.
In one patient with untreated recurrent Graves' disease, a single dose of $1 \mathrm{Gm}$. progoitrin was given once daily over a period of one month to evaluate its efficacy in the treatment of thyrotoxicosis when administered in this manner.

The antithyroid potency of progoitrin was also tested in 100 to $120 \mathrm{Gm}$. male Holtzman rats. It was given orally, subcutaneously or intraperitoneally in physiologic saline at various intervals prior to administration of $0.2 \mu \mathrm{c}$. $\mathrm{I}^{131}$ in $0.2 \mathrm{ml}$. physiologic saline intraperitoneally. The animals were killed four and one-half hours after receiving radioiodine, the thyroids dissected and their radioactivity determined in a well scintillation counter.

\section{RESULTS}

\section{Studies in man}

A. Acute inhibition of radioiodine uptake. The inhibition of the "accumulation gradient" following the ingestion of 0.5 to $2.0 \mathrm{Gm}$. of progoitrin orally was studied in one thyrotoxic and seven euthyroid volunteers. The results are summarized in Table $I$ and in Figures 1 and 2. In five of these subjects, myrosin was given in addition at the same time; in two of these five the progoitrin had been incubated with myrosin overnight at $37^{\circ}$ in a $\mathrm{pH} 5.6$ phosphate buffer. The degree of inhibition of the accumulation gradient was arbitrarily graded from zero to five according to the system previously used (3).

It is apparent that inhibition of the acute uptake of radioiodine was produced by the ingestion of progoitrin. Prior incubation of progoitrin with myrosin or the addition of this enzyme at the time of progoitrin administration did not seem to affect the results materially.

The interval from ingestion of progoitrin to a

TABLE I

Inhibition of accumulation gradient by oral progoitrin $(P G)$ in euthyroid patients *

\begin{tabular}{|c|c|c|c|c|c|c|c|}
\hline Patient & $\begin{array}{c}\text { Accumu- } \\
\text { lation } \\
\text { gradient }\end{array}$ & Interval & Dose PG & Myrosin & $\begin{array}{l}\text { Expected } 24 \\
\text { hr. uptake }\end{array}$ & $\begin{array}{l}\text { Actual } 24 \\
\text { hr. uptake }\end{array}$ & $\begin{array}{c}\text { Grade of } \\
\text { inhibition } \dagger\end{array}$ \\
\hline $\begin{array}{l}\text { W. H. } \\
\text { M. K. } \\
\text { C. K. } \\
\text { M. M. } \\
\text { A. K. } \\
\text { M. L. } \\
\text { L. R. }\end{array}$ & $\begin{array}{l}1.28 \\
1.28 \\
1.95 \\
1.20 \\
1.37 \\
0.58 \\
0.68\end{array}$ & $\begin{array}{r}\min . \\
216 \\
139 \\
95 \\
166 \\
116 \\
251 \\
104\end{array}$ & $\begin{array}{r}G m . \\
0.5 \\
0.5 \\
2.0 \\
2.0 \\
2.0 \\
2.0 \\
2.0\end{array}$ & $\begin{array}{l}+t \\
+ \\
+ \\
+ \\
+t\end{array}$ & $\begin{array}{l}34.6 \\
34.6 \\
48.4 \\
32.7 \\
36.6 \\
17.0 \\
19.7\end{array}$ & $\begin{array}{l}24.5 \\
26.6 \\
22.5 \\
16.1 \\
18.8 \\
10.5 \\
12.0\end{array}$ & $\begin{array}{l}2 \\
2 \\
5 \\
5 \\
5 \\
5 \\
5\end{array}$ \\
\hline
\end{tabular}

* Interval = time from administration of progoitrin to beginning inhibition of radioiodine uptake. Ten ml. myrosin was given with progoitrin where indicated.

+ Grade of inhibition is based on a scale of $0=$ no effect and $5=$ complete inhibition for 24 hours (3).

$\ddagger$ Myrosin was incubated with progoitrin for 18 hours before administration. 


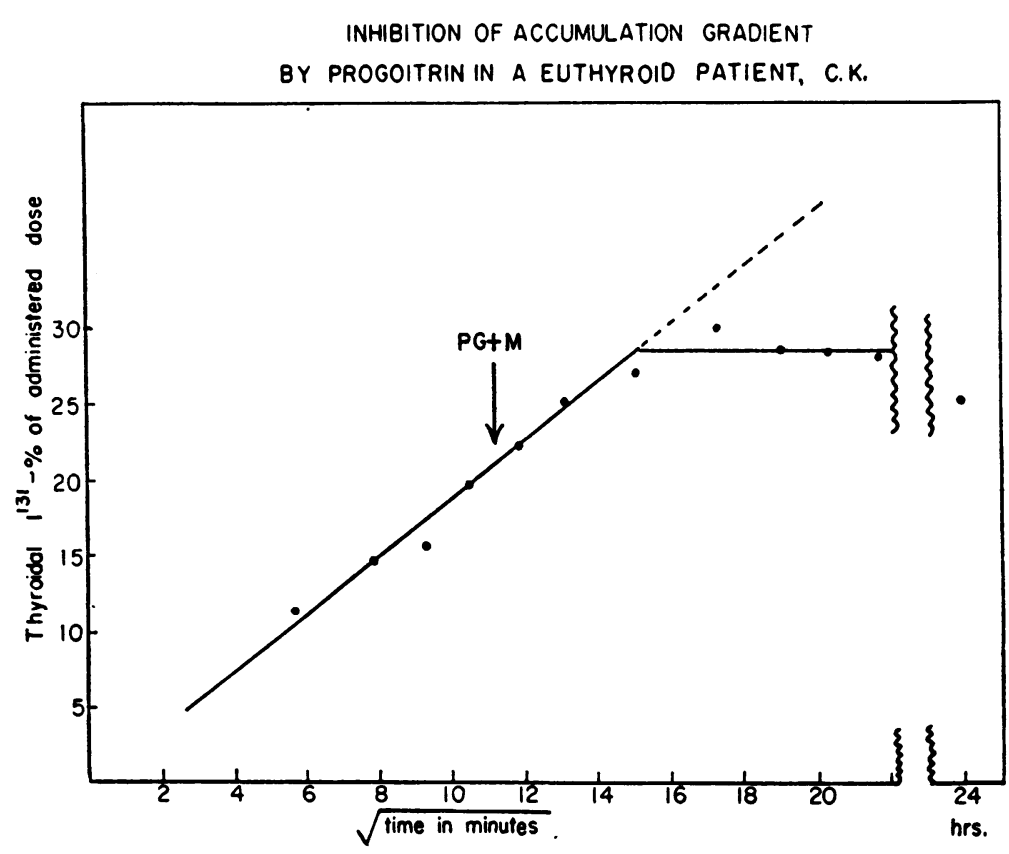

Fig. 1. Inhibition of Accumulation Gradient by Simultaneous Oral Administration of 2 Gm. Progoitrin and 10 ml. Myrosin Solution $(\mathrm{PG}+\mathrm{M})$

detectable change in the slope of the accumulation gradient was somewhat longer than had previously been obtained when raw rutabagas and turnips were fed.

Inhibition of radioiodine uptake by progoitrin appeared to be just as effective in the thyrotoxic as in the euthyroid patients. The day prior to the progoitrin study, the 24 hour radioiodine uptake in this patient was 71 per cent. Following the appearance of obvious inhibition of the accumula-

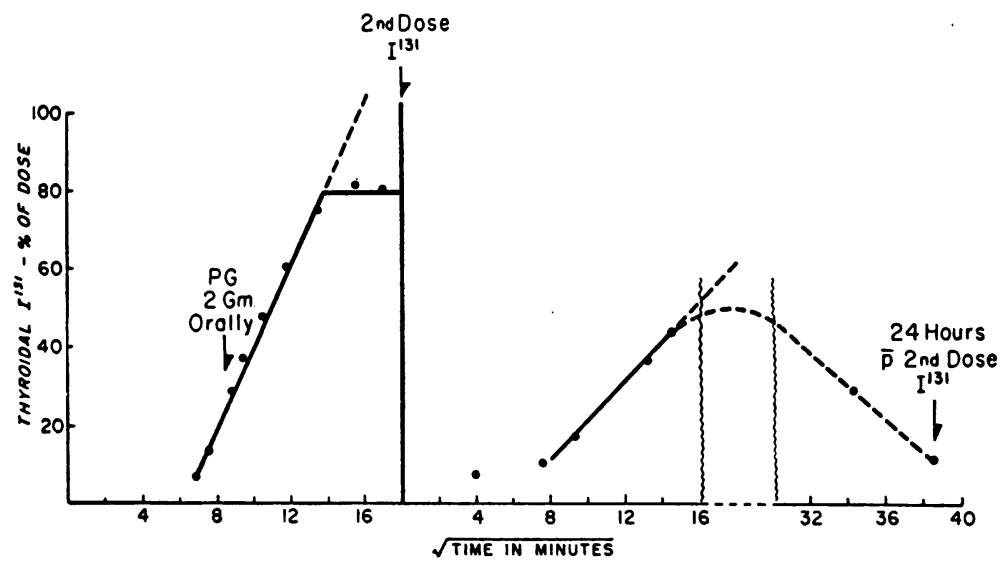

Fig. 2. Inhibition of Accumulation Gradient in a Thyrotoxic Patient (L.B.) Given 2 Gm. Progoitrin Orally

The "second dose" of $\mathrm{I}^{131}$ on the graph is referred to as the third dose of $\mathrm{I}^{131}$ in the text since the patient had an initial radioiodine uptake before the studies graphically presented here were undertaken. The radioactivity remaining from the preceding dose of radioiodine was subtracted from the thyroidal counts in calculating the per cent of the administered dose in the thyroid. 


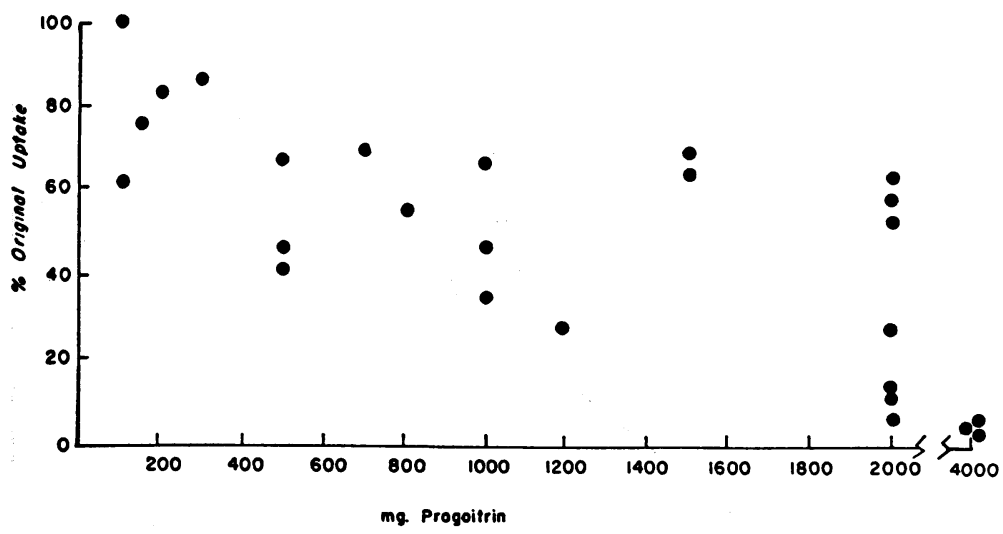

Fig. 3. Plot of the Suppressive Effect of Varying Doses of Oral Progoitrin on the Radiolodine Uptake in Euthyroid Patients

Each point represents the uptake following progoitrin expressed as per cent of the control uptake in a single patient.

tion gradient by progoitrin, a third tracer dose of radioiodine was given. Although a considerable portion of this third dose rapidly accumulated in the thyroid gland, most of it had been lost from the thyroid 24 hours later (Figure 2). The 24 hour thyroidal accumulation of the third dose was only 11 per cent compared to the previous 71 per cent. The rapid concentration and release of this last tracer dose is characteristic of the behavior one would expect of unbound iodide.

$B$. Inhibition of the 24 hour radioiodine uptake. Since progoitrin seemed to possess antithyroid

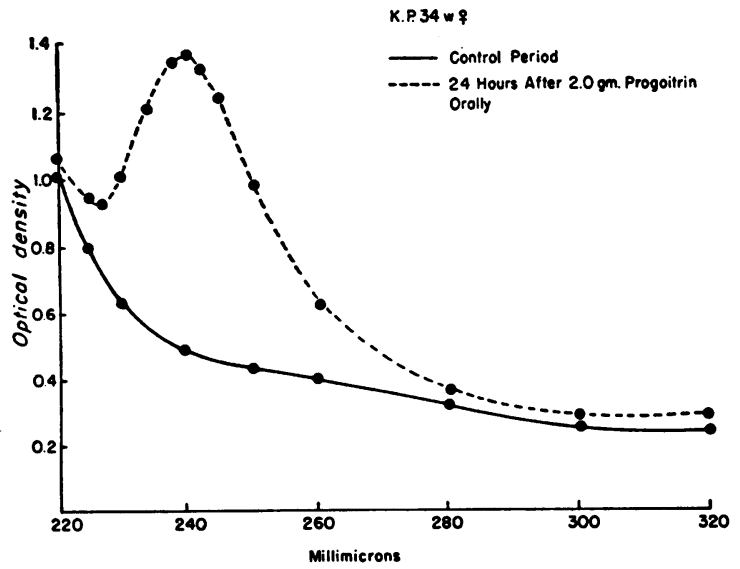

Fig. 4. Ether Extracts of Urine

Note the absorption peak at $240 \mathrm{~m} \mu$ characteristic of goitrin which appears in ether extracts of urine after administration of progoitrin. activity when administered without added myrosin, in the following studies progoitrin alone was used. As a preliminary control study (although the technique had previously been investigated) two consecutive 24 hour uptakes were performed in seven euthyroid subjects. The mean value for the second 24 hour uptake was $111 \pm 1.9$ per cent of the initial uptake. A second uptake lower than the first was not observed.

The effect of oral progoitrin on the second uptake was then studied in 23 additional volunteers. The doses ranged from 0.1 to $4.0 \mathrm{Gm}$. and the results are graphically plotted in Figure 3.

Considerable variation in the response to a given dose existed, but there was a definite trend toward a more pronounced effect with increasing doses. In one subject, $100 \mathrm{mg}$. produced no change in the uptake while in another the same dose lowered the second uptake to 61.5 per cent of the first. Similarly, when $2.0 \mathrm{Gm}$. was administered, the second uptake ranged from 6.0 to 62.5 per cent of the first.

C. Recovery of goitrin from blood and urine. Complete aliquot collections of urine and serial samples of blood extending over a period of several days were studied in nine subjects following ingestion of $150 \mathrm{mg}$. to $4.0 \mathrm{Gm}$. progoitrin. Only in those receiving at least $1.5 \mathrm{Gm}$. progoitrin was it possible to clearly demonstrate goitrin in the blood and urine. 
Because of the inconstant nonspecific absorption of the ether extracts of urine and blood at $240 \mathrm{~m} \mu$, it was difficult to obtain completely quantitative estimates of the goitrin in the samples. A positive response was considered one in which there was higher absorption at 240 than at 230 or $250 \mathrm{~m} \mu$. When the peak at $240 \mathrm{~m} \mu$ was significantly above the other two readings (Figure 4), a semiquantitative calculation of the goitrin concentration was made, using the previously determined specific absorption of goitrin at $240 \mathrm{~m} \mu$ (4). Since no correction for nonspecific absorption was made in these calculations, the recorded values are probably somewhat higher than they should be. It was not considered practical to try to devise an adequate correction system, however. A peak of absorption at $240 \mathrm{~m} \mu$ in ether extracts of urine and blood was never seen in patients who had not received either goitrin or progoitrin (Figure 4).

When $4 \mathrm{Gm}$. of progoitrin was administered orally, goitrin was detected in both blood and urine for up to four days. In one patient studied one month after ingestion of $10 \mathrm{mMoles}(4 \mathrm{Gm}$.) of progoitrin, $10 \mathrm{mMoles}$ of goitrin $(1.29 \mathrm{Gm}$.) was given and similar blood and urine studies made (Figure 5). The total excretion of goitrin in both instances was almost identical (103 vs. $108 \mathrm{mg}$. over the entire period). However, after progoitrin administration the serum goitrin concentration reached a maximum at approximately 35 hours, while a maximum was reached within the first half hour after goitrin was given. The excretion and blood concentration of goitrin in the other patients receiving large doses of progoitrin and in one other patient who received goitrin were similar.

No ill effects were seen after oral progoitrin, but both patients who received the purified goitrin became nauseated and vomited a few hours later. In one of the patients, nausea and vomiting persisted for two days. Since gastrointestinal distress had never been seen in the earlier studies with pure crystalline goitrin (9), it is unlikely that this discomfort was produced by the goitrin per se. A more reasonable explanation is that the purified goitrin preparation used in the present studies contained trace amounts of offensive impurities responsible for the nausea. The material had an unpleasant aromatic taste and odor.
Radioiodine uptake studies were performed in two of the patients receiving $4 \mathrm{Gm}$. progoitrin and in both patients who received goitrin. In both groups of patients, uptake was suppressed for several days after administration of the test substance. The length of inhibition of radioiodine uptake seemed to correlate well with the blood and urine content of goitrin.

D. Rectal administration of progoitrin. Certain evidence, to be alluded to below, indicated that hydrolysis of progoitrin might occur in the large intestine. It is well known, however, that some substances are not appreciably absorbed once they pass through the small intestine. To ascertain whether hydrolysis of progoitrin might actually occur in the colon and whether absorption therefrom could take place, $4 \mathrm{Gm}$. of progoitrin dissolved in saline was administered by rectal tube to three subjects. In two of the volunteers, goitrin could subsequently be detected in the urine and in one of these it was also found in the blood. One

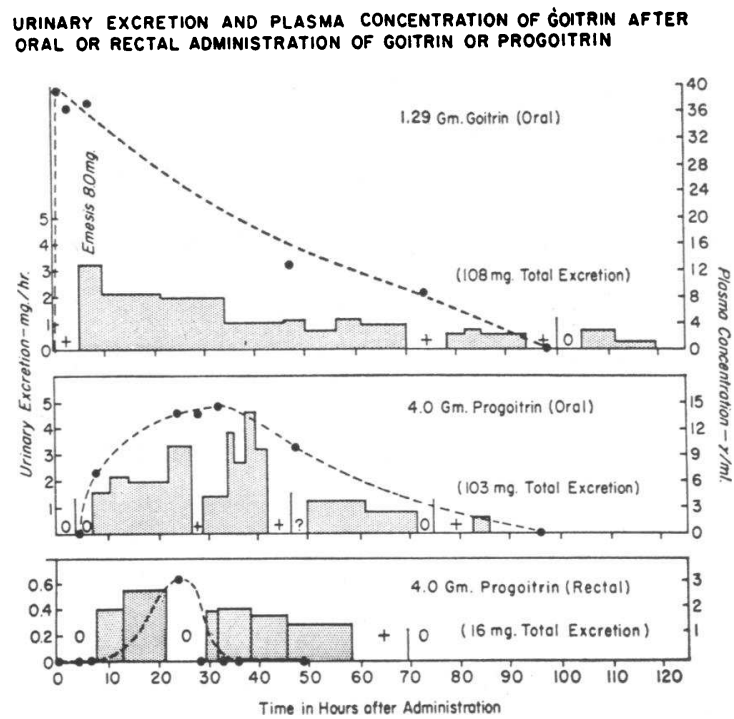

Fig. 5. Successive Studies of Serum Concentration and Urinary Excretion of Goitrin in the Same Patient (M.M.) after Administration of Equivalent Amounts of Oral and Rectal Progoitrin and Oral GoITRIN

Note emesis of $8.0 \mathrm{mg}$. goitrin following oral goitrin administration. The dotted line represents serum concentration and the solid bars urinary excretion. $0=$ no goitrin detectable; $+=$ goitrin detectable but urine volume unknown or amount of goitrin too small to make accurate calculation; ?= urine sample inadvertently discarded. 


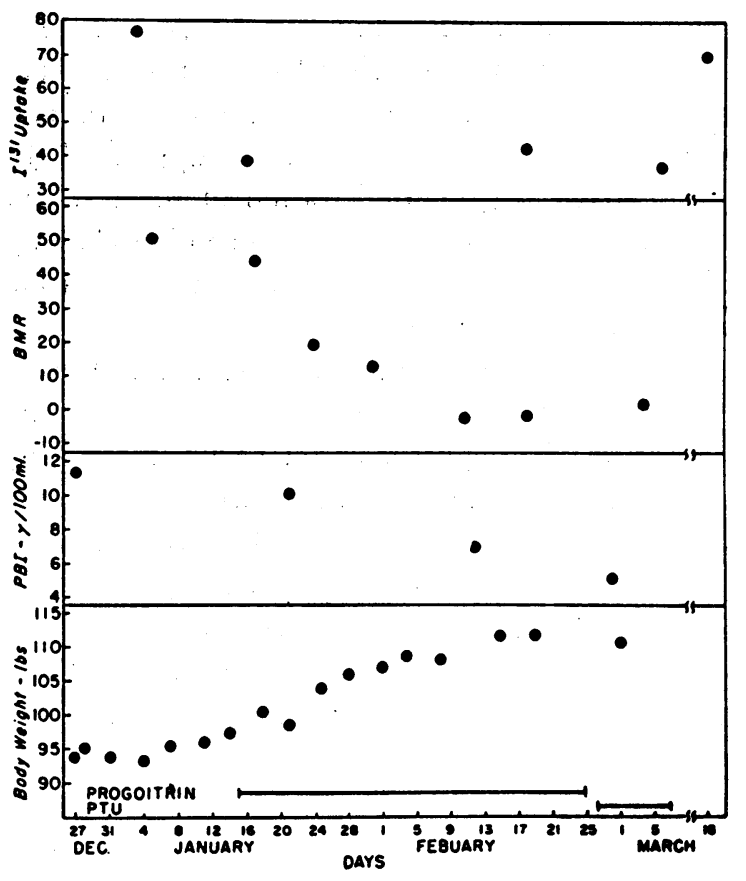

Fig. 6. Graves' Disease Treated with 1 Gm. Progoitrin or 300 mg. Propylthiouracil (PTU) Once Daily (Patient W.L.)

One $\mathrm{Gm}$. progoitrin or $300 \mathrm{mg}$. propylthiouracil was given once daily during indicated intervals. $\mathrm{I}^{131}$ uptake is expressed as per cent of administered dose in the thyroid gland at 24 hours. Basal metabolic rate (BMR) is expressed as per cent above normal. Protein-bound iodine (PBI) is expressed as $\mu \mathrm{g}$. per $100 \mathrm{ml}$. serum.

of these subjects had previously received equivalent amounts of both goitrin and progoitrin orally. Comparison of the results of her three studies (Figure 5) indicated that a much smaller quantity of goitrin was excreted in the urine after rectal than after oral administration (16 vs. $103 \mathrm{mg}$ ).

The one patient in whom goitrin could not be detected developed a watery diarrhea soon after instillation of the progoitrin. It is possible that the failure to detect the liberation of goitrin in this case was due to elimination of the progoitrin before adequate hydrolysis had occurred. Unfortunately, it was not possible to obtain stool analyses in any of the three subjects.

E. Therapy of hyperthyroidism. In order to assess the clinical efficacy of the apparent antithyroid effect of progoitrin, $1 \mathrm{Gm}$. once daily in a glass of orange juice was administratered to a patient with fairly severe recurrent Graves' disease. Serial determinations were made of the patient's weight, serum protein-bound iodine, radioiodine uptake and basal metabolic rate during the month of progoitrin therapy. In addition, the effect of a comparable dose of propylthiouracil (300 mg.) once daily was studied for a period of nine days beginning at the conclusion of the progoitrin period.

The results are summarized in Figure 6. It can be seen that a gratifying clinical response to progoitrin was made. There was a progressive fall in the BMR and PBI and a gradual increase in body weight beginning very shortly after initiation of progoitrin therapy. The 24 hour radioiodine uptake was decreased from a pretreatment level of 77 per cent to 39 to 44 per cent during the progoitrin period. A similar value of 39 per cent was obtained when medication had been shifted

TABLE II

Effect of oral progoitrin, with or without myrosin, on I'131 uptake*

\begin{tabular}{|c|c|c|c|c|}
\hline \multirow{2}{*}{$\begin{array}{l}\text { Experiment } \\
\text { and group }\end{array}$} & \multirow{2}{*}{$\begin{array}{c}\text { No. of } \\
\text { animals }\end{array}$} & \multirow[b]{2}{*}{ Dose } & \multicolumn{2}{|c|}{ I'11 uptake } \\
\hline & & & Dose & Controls \\
\hline $\mathbf{I}$ & & mg. & $\%$ & $\%$ \\
\hline $\begin{array}{l}\text { Control } \\
\text { PG } \\
\text { PG }+M \\
\text { PTU }\end{array}$ & $\begin{array}{l}4 \\
4 \\
4 \\
4\end{array}$ & $\begin{array}{l}20 \\
20 \\
10\end{array}$ & $\begin{array}{l}1.25 \pm 0.03 \\
1.04 \pm 0.21 \\
2.31 \pm 0.37 \\
0.10 \pm 0.01\end{array}$ & $\begin{array}{r}100.0 \pm 2.4 \\
83.2 \pm 16.8 \\
184.8 \pm 29.6 \\
8.0 \pm 0.8\end{array}$ \\
\hline $\begin{array}{l}\text { II } \\
\text { Control } \\
\text { PG } \\
\text { PG }+ \text { M } \\
\text { PTU }\end{array}$ & $\begin{array}{l}6 \\
6 \\
6 \\
6\end{array}$ & $\begin{array}{r}200 \\
200 \\
5\end{array}$ & $\begin{array}{l}1.37 \pm 0.34 \\
0.91 \pm 0.28 \\
0.17 \pm 0.04 \\
0.21 \pm 0.12\end{array}$ & $\begin{array}{r}100.0 \pm 24.8 \\
66.4 \pm 20.4 \\
12.4 \pm 3.1 \\
15.3 \pm 8.8\end{array}$ \\
\hline
\end{tabular}

* Results are expressed as mean and standard error. Animals were maintained on Purina Laboratory Chow (B. $\mathrm{PG}=$ progoitrin $; \mathrm{M}=1 \mathrm{ml}$. myrosin given orally simultaneously with progoitrin $; \mathrm{PTU}=$ propylthiouracil, administered subcutaneously. 
TABLE III

Inhibition of $I^{131}$ uptake by progoitrin when given at varying intervals preceding radioiodine *

\begin{tabular}{|c|c|c|c|c|c|}
\hline \multirow{2}{*}{$\begin{array}{l}\text { Experiment } \\
\text { and group }\end{array}$} & \multirow{2}{*}{$\begin{array}{l}\text { No. of } \\
\text { animals }\end{array}$} & \multirow[b]{2}{*}{ Dose } & \multirow{2}{*}{$\underset{\substack{\text { Hours } \\
\text { preding }}}{\text { Hoceding }}$} & \multicolumn{2}{|c|}{ In uptake } \\
\hline & & & & Dose & Controls \\
\hline & & $m g$. & & $\%$ & $\%$ \\
\hline $\begin{array}{l}\text { Control } \\
\text { PG }+M \\
\text { PG }+M \\
\text { PTU }\end{array}$ & $\begin{array}{l}5 \\
5 \\
5 \\
5\end{array}$ & $\begin{array}{r}100 \\
100 \\
10\end{array}$ & $\begin{array}{r}19 \\
1 \\
1\end{array}$ & $\begin{array}{l}3.11+0.40 \\
1.28 \pm 0.26 \\
0.83 \pm 0.13 \\
0.23 \pm 0.03\end{array}$ & $\begin{array}{r}100.0 \pm 12.9 \\
41.0 \pm 8.4 \\
26.7 \pm 4.2 \\
7.4 \pm 1.0\end{array}$ \\
\hline $\begin{array}{l}\text { IV } \\
\text { Control } \\
\text { PG } \\
\text { PG } \\
\text { PG } \\
\text { PG }+M \\
\text { PG } \\
\text { PG }+M \\
\text { PTU }\end{array}$ & $\begin{array}{l}5 \\
5 \\
5 \\
5 \\
5 \\
5 \\
5 \\
5\end{array}$ & $\begin{array}{r}300 \\
300 \\
300 \\
300 \\
300 \\
300 \\
10\end{array}$ & $\begin{array}{c}23.5 \\
19.5 \\
17.5 \\
17.5 \\
1 \\
1 \\
1\end{array}$ & $\begin{array}{l}3.78 \pm 0.36 \\
1.62 \pm 0.21 \\
1.92 \pm 0.42 \\
1.56 \pm 0.27 \\
1.35 \pm 0.37 \\
1.43 \pm 0.31 \\
0.96 \pm 0.22 \\
0.37 \pm 0.12\end{array}$ & $\begin{array}{r}100.0 \pm 9.5 \\
42.9 \pm 5.6 \\
50.8 \pm 11.1 \\
41.3 \pm 7.1 \\
35.7 \pm 9.8 \\
37.8 \pm 8.2 \\
25.4 \pm 5.8 \\
9.8 \pm 3.2\end{array}$ \\
\hline
\end{tabular}

* Progoitrin was given orally at indicated intervals preceding ${ }^{131}$. Abbreviations are identical to those in Table II. Rats were fed Purina Laboratory Chow ${ }^{\circledR}$.

to propylthiouracil. Eleven days after propylthiouracil had been discontinued, the uptake had risen again to 70 per cent.

\section{Studies in the rat}

A. Oral progoitrin. Progoitrin, with or without myrosin, was given by stomach tube in several experiments (Table II). Inhibition of radioiodine uptake was regularly induced when an adequate dose of progoitrin was administered, but inhibition did not equal that obtained from the injection of 5 to $10 \mathrm{mg}$. propylthiouracil. Previous studies had shown that propylthiouracil was 55 times more active than goitrin in the rat (9). Since enzymatic hydrolysis of progoitrin will yield only 32.2 per cent goitrin by weight, $1.7 \mathrm{Gm}$. of progoitrin (assuming complete hydrolysis) would be required to equal $10 \mathrm{mg}$. propylthiouracil. Unfortunately, when large doses were given the animals developed diarrhea and became ill. Thus the failure to obtain a suppression from progoitrin equivalent to that produced by propylthiouracil may be attributed to the rapid passage of the orally administered material through the intestinal tract before adequate hydrolysis or absorption could take place.

Because of the relatively slow hydrolysis of progoitrin, we were not sure what interval between progoitrin and $\mathrm{I}^{131}$ administration would be optimal to detect antithyroid activity. For this reason the time interval between administra- tion of the two materials was varied in some experiments (Table III). No significant dissimilarity was seen, although a shorter interval appeared to produce somewhat greater depression of the $\mathrm{I}^{131}$ uptake.

During the early studies with orally administered progoitrin, the rats were fed Purina Laboratory Chow. Since the iodine content of this preparation is quite high, the radioiodine uptakes were correspondingly rather low and the significance of the differences between the groups is probably not as great as in the later experiments where a low iodine diet was used.

B. Comparison of oral vs. systemic progoitrin. To ascertain whether hydrolysis occurred in the gut or after unchanged progoitrin had been absorbed from the alimentary tract, comparison of the inhibitory effect of the same amounts of progoitrin administered orally and subcutaneously or intraperitoneally was studied in several experiments (Table IV). With lower doses of progoitrin, a much more pronounced inhibition of radioiodine uptake was produced with oral than with systemic administration. When larger doses were employed, however, there was some increase in the efficacy of systemic progoitrin whereas oral progoitrin became less effective. This decreased potency with increasing doses of oral progoitrin was probably related to the severe diarrhea which occurred when large doses were tube fed and has been mentioned above. 
TABLE IV

Comparison of inhibition produced by oral vs. systemic progoitrin *

\begin{tabular}{|c|c|c|c|c|c|c|}
\hline \multirow{2}{*}{$\begin{array}{l}\text { Experiment } \\
\text { and group }\end{array}$} & \multirow{2}{*}{$\begin{array}{c}\text { No. of } \\
\text { animals }\end{array}$} & \multirow{2}{*}{$\begin{array}{c}\text { Route of } \\
\text { adminis- } \\
\text { tration }\end{array}$} & \multirow[b]{2}{*}{ Dose } & \multirow{2}{*}{$\underset{\substack{\text { Hours } \\
\text { preceding }}}{\text { I31 }}$} & \multicolumn{2}{|c|}{ I'131 uptake } \\
\hline & & & & & Dose & Controls \\
\hline & & & $m g$. & & $\%$ & $\%$ \\
\hline $\begin{array}{l}\text { Control } \\
\text { PG } \\
\text { PG } \\
\text { PTU }\end{array}$ & $\begin{array}{l}6 \\
6 \\
6 \\
6\end{array}$ & $\begin{array}{l}\text { p. o. } \\
\text { s. c. } \\
\text { s. c. }\end{array}$ & $\begin{array}{r}200 \\
200 \\
5\end{array}$ & $\begin{array}{l}3 \\
3 \\
3\end{array}$ & $\begin{array}{r}38.81 \pm 2.79 \\
13.11 \pm 0.79 \\
31.28 \pm 3.03 \\
1.96 \pm 0.28\end{array}$ & $\begin{array}{r}100.0 \pm 7.2 \\
33.8 \pm 20 \\
80.6 \pm 7.8 \\
5.1 \pm 0.7\end{array}$ \\
\hline $\begin{array}{c}\text { VI } \\
\text { Control } \\
\text { PG } \\
\text { PG } \\
\text { PTU }\end{array}$ & $\begin{array}{l}6 \\
6 \\
6 \\
6\end{array}$ & $\begin{array}{l}\text { p. o. } \\
\text { s. c. } \\
\text { s. c. }\end{array}$ & $\begin{array}{r}625 \\
625 \\
5\end{array}$ & $\begin{array}{l}3 \\
3 \\
3\end{array}$ & $\begin{array}{r}37.80 \pm 3.28 \\
12.03 \pm 4.43 \\
27.90 \pm 5.57 \\
2.07 \pm 0.22\end{array}$ & $\begin{array}{r}100.0 \pm 8.7 \\
31.8 \pm 11.7 \\
73.8 \pm 14.7 \\
5.5 \pm 0.6\end{array}$ \\
\hline $\begin{array}{l}\text { VII } \\
\text { Control } \\
\text { PG } \\
\text { PG } \\
\text { PTU }\end{array}$ & $\begin{array}{l}4 \\
2 \\
3 \\
3\end{array}$ & $\begin{array}{l}\text { p. o. } \\
\text { i. p. } \\
\text { s. c. }\end{array}$ & $\begin{array}{r}1,000 \\
1,000 \\
6\end{array}$ & $\begin{array}{l}17 \\
17 \\
17\end{array}$ & $\begin{array}{r}26.62 \pm 1.63 \\
22.01 \pm 3.68 \\
14.93 \pm 1.55 \\
2.90 \pm 1.94\end{array}$ & $\begin{array}{r}100.0 \pm 6.1 \\
82.7 \pm 13.8 \\
56.1 \pm 5.8 \\
10.9 \pm 7.3\end{array}$ \\
\hline $\begin{array}{c}\text { VIII } \\
\text { Control } \\
\text { PG } \\
\text { PG } \\
\text { PTU }\end{array}$ & $\begin{array}{l}6 \\
6 \\
6 \\
6\end{array}$ & $\begin{array}{l}\text { p. o. } \\
\text { i. p. } \\
\text { s. c. }\end{array}$ & $\begin{array}{r}1,000 \\
1,000 \\
5\end{array}$ & $\begin{array}{l}4 \\
4 \\
2.5\end{array}$ & $\begin{array}{r}28.92 \pm 1.32 \\
16.84 \pm 1.11 \\
12.00 \pm 3.28 \\
1.65 \pm 0.19\end{array}$ & $\begin{array}{r}100.0 \pm 4.6 \\
58.2 \pm 3.8 \\
41.5 \pm 11.3 \\
5.7 \pm 0.7\end{array}$ \\
\hline
\end{tabular}

* Progoitrin was given at indicated intervals preceding $\mathrm{I}^{131}$. Abbreviations are identical to those in Table II; in addition, p. $o .=$ orally, s. c. $=$ subcutaneously, i. p. $=$ intraperitoneally. All rats were fed a low iodine diet for one week prior to study.

\section{DISCUSSION}

It seems clear that our earlier hypothesis that progoitrin could only be converted to goitrin by exogenously supplied myrosin is in error. Although it is possible that progoitrin may possess some antithyroid activity itself, exclusive of the goitrin it produces, this does not seem likely. Other mustard oil thioglycosides with a structure similar to progoitrin have not been found to possess goitrogenic properties. Only those few thioglycoside aglycones which are converted to thiona-
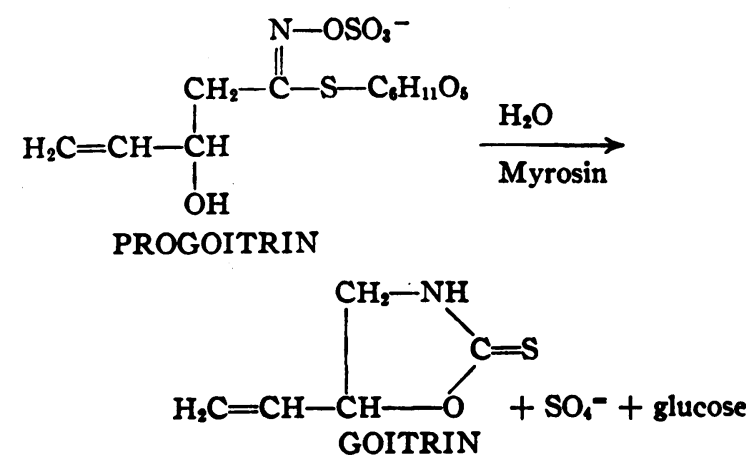

Fig. 7. Enzymatic Conversion of Progoitrin to GoItrin BY Myrosin mides on hydrolysis are goitrogenic. Since goitrin is not present as such in the progoitrin molecule, but as an aliphatic secondary alcohol without a thionamide grouping and with cyclization to form goitrin occurring on hydrolysis (Figure 7), it is very unlikely that progoitrin by itself would have any activity. In vitro studies with thyroid slices in this laboratory have shown that goitrin will completely block organic binding of iodine whereas progoitrin is inactive (13). In addition to theoretical objections, from the studies made of the recovery of goitrin from blood and urine after administration of progoitrin, it appears that the precursor is quantitatively converted to the active antithyroid compound in the body. The calculated conversion would adequately explain the observed activity.

The site of hydrolysis is unknown at present. From the considerably less effective inhibition of radioiodine uptake produced by systemic compared to oral progoitrin it seems possible that this hydrolysis may occur predominantly in the gastrointestinal tract. The inhibition produced by large doses of systemic progoitrin may be due to escape of some of this material into the gut. In vitro studies of various tissues and body fluids 
from rats and man have so far revealed thioglycosidase activity only in the gastrointestinal tract and its contents, including feces (13).

A number of attempts have been made to elucidate the origin of the thioglycosidase in feces. Since such activity had recently been reported in fungi (14), it appeared probable that some sort of microorganism was producing the fecal thioglycosidase. In spite of diligent effort, however, it has so far not been possible to isolate any thioglycosidase-producing organism from the stool (13). None of the common colon inhabitants seem to elaborate this enzyme.

Even if the thioglycosidase activity were due to gastrointestinal organisms, there was some question whether absorption of goitrin from the colon would occur. This was answered by the experiments in which progoitrin was administered by rectal tube. Significant quantities of goitrin were found to appear in the blood and urine following this procedure, although the quantities were much less than following oral administration of the same amount of progoitrin. However, in view of the appearance of goitrin in blood and urine and the concomitant demonstration of antithyroid activity as early as one to three hours after oral progoitrin administration, it is probable that some hydrolysis and absorption also occur higher in the gastrointestinal tract.

It is rather puzzling that consistent antithyroid activity was not detected in our earlier studies when cooked rutabagas and turnips were fed. In part this may be related to the delayed onset of inhibition of the accumulation gradient when pure progoitrin was given and the rather prompt onset of inhibition in the studies with whole foods. An effect from the cooked foods may have appeared so late as to be ignored as an artifact. Actually on re-examining the earlier data, it is apparent that occasionally an inhibition of the accumulation gradient did occur when cooked crucifers were given. Illustration of such inhibition was even published and commented on in the original article (3).

At present, we can say that, in most people, eating cooked vegetables containing progoitrin should be just as likely to produce goiter as eating them raw. There does seem to be some variation in the antithyroid effect of the same dose of progoitrin in different individuals (Figure 3) but it is not clear whether this is due to individual variations in the thioglycosidase activity of their gastrointestinal tracts or in the response of their thyroid glands to antithyroid compounds.

Progoitrin seems to hold some promise as an effective antithyroid compound in the treatment of thyrotoxicosis. Because of its prolonged effect when given in large doses, it was thought that the delayed hydrolysis of this compound would permit an adequate therapeutic effect if it were given only once daily or even less often. In the one hyperthyroid patient treated, a very satisfactory response was obtained over the month such therapy was exhibited.

It also appears that the prolonged effectiveness of single large doses of progoitrin is not entirely due to the slow hydrolysis after oral ingestion. When equivalent amounts of both goitrin and progoitrin were given to the same patient, although there was a much more rapid rise in blood levels after goitrin was given, the total length of time during which goitrin could be detected in blood and urine and the duration of radioiodine inhibition were the same with both drugs (Figure 5). The radioiodine uptake in the thyrotoxic patient under long-term treatment with progoitrin also was depressed to just as great an extent by an equivalent $(300 \mathrm{mg}$.) dose of propylthiouracil administered once daily (Figure 6 ).

It is probable that the duration of action of progoitrin or goitrin is more related to the quantity given than to any peculiar metabolism of these compounds in comparison with other antithyroid substances. Such a direct relation of length of action to dosage had been demonstrated with a variety of goitrogenic drugs some time ago by Stanley and Astwood (11).

\section{SUM MARY}

Previous studies have shown that certain foods, especially rutabaga and turnip, possess antithyroid activity in man. The active antithyroid principle of the turnip family, goitrin, is released from a precursor, progoitrin, by enzymatic action. Earlier studies had indicated that cooking foods containing progoitrin would destroy myrosin, the specific hydrolytic enzyme which liberates goitrin from progoitrin. Therefore the cooked foods would have no antithyroid activity when eaten. 
Studies were made with crystalline progoitrin in man and the laboratory rat employing inhibition of radioiodine uptake as an index of antithyroid activity. Contrary to expectations, it was found that progoitrin would produce consistent antithyroid activity either with or without simultaneous administration of myrosin. It was possible to identify the appearance of goitrin in the blood and urine by spectrophotometric analysis and to determine that the yield of goitrin from progoitrin was quantitative. This indicated that hydrolysis of progoitrin occurs within the body in the absence of exogenous myrosin. This demonstration of antithyroid activity following the administration of pure progoitrin suggests that our concept regarding the innocuousness of cooked crucifers in the production of simple goiter should be revised.

Progoitrin administered in a single daily dose of $1 \mathrm{Gm}$. was found an effective agent in the treatment of thyrotoxicosis in one patient.

\section{ACKNOWLEDGMENT}

The authors gratefully acknowledge the assistance of Miss Sanomar Barr and Mrs. Barbara Loomis in these studies.

\section{REFERENCES}

1. Chesney, A. M., Clawson, T. A., and Webster, B. Endemic goitre in rabbits. I. Incidence and characteristics. Bull. Johns Hopk. Hosp. 1928, 43, 261.

2. Greer, M. A. Nutrition and goiter. Physiol. Rev. 1950, 30, 513.
3. Greer, M. A., and Astwood, E. B. The antithyroid effect of certain foods in man as determined with radioactive iodine. Endocrinology 1948, 43, 105.

4. Astwood, E. B., Greer, M. A., and Ettlinger, M. G. L-5-vinyl-2-thiooxazolidone, an antithyroid compound from yellow turnip and from Brassica seeds. J. biol. Chem. 1949, 181, 121.

5. Greer, M. A. Isolation from rutabaga seed of progoitrin, the precursor of the naturally occurring antithyroid compound, goitrin (L-5-vinyl-2-thiooxazolidone). J. Amer. chem. Soc. 1956, 78, 1260.

6. Virtanen, A. I., Kruela, M., and Kiesvaara, M. The transfer of L-5-vinyl-2-thiooxazolidone (oxazolidine-thione) to milk. Acta chem. scand. 1958, 12, 580.

7. Altamura, M. R., Long, L., Jr., and Hasselstrom T. Goitrin from fresh cabbage. J. biol. Chem. 1959, 234, 1847.

8. Wrede, F. Thioglukosidase in Die Methoden der Fermentforschung. E. Bamann \& K. Myrbäck, Eds. Leipzig, Georg Thieme, 1940, vol. 5, p. 1834.

9. Greer, M. A., Ettlinger, M. G., and Astwood, E. B. Dietary factors in the pathogenesis of simple goiter. J. clin. Endocr. 1949, 9, 1069.

10. Greer, M. A. In preparation.

11. Stanley, M. M., and Astwood, E. B. Determination of the relative activities of antithyroid compounds in man using radioactive iodine. Endocrinology 1947, 41, 66.

12. Greer, M. A. Correlation of the 24 -hour radioiodine uptake of the human thyroid gland with the sixand eight-hour uptakes and the "accumulation gradient." J. clin. Invest. 1951, 30, 301.

13. Deeney, J. M., Iino, S., and Greer, M. A. Unpublished data.

14. Reese, E. T., Clapp, R. C., and Mandels, M. A thioglucosidase in fungi. Arch. Biochem. 1958, $75,228$.

\section{SPECIAL NOTICE TO SUBSCRIBERS}

Post Offices will no longer forward the Journal when you move.

Please notify The Journal of Clinical Investigation, Business

Office, 333 .Cedar Street, New Haven 11, Conn., at once when you have a change of address, and do not omit the zone number if there is one. 